\title{
Redevelopment of urban areas
}

\author{
Azarii Lapidus ${ }^{1[0000-0001-7846-5770]}$, and Dmitry Topchiy ${ }^{1}{ }^{*}$ 0000-0002-3697-9201] \\ ${ }^{1}$ Moscow State University of Civil Engineering, 129337, Yaroslavskoe Highway, Moscow, Russia
}

\begin{abstract}
In the context of ongoing transformations in society and the globalization of economic relations, the objects of the spatial environment of modern urban areas are also changing. The trend towards redevelopment or re-profiling of the urban environment in the direction of greening and increasing the comfort of living of the urban population is becoming more and more significant. These changes have become popular in a number of large cities in Russia due to the huge rate of population urbanization and the movement from small settlements towards megacities or large population centers. As a result, some of the territories occupied in the past years by the industrial sector, dilapidated production bases, transport hangars, and in some cases, dilapidated residential buildings have turned into modern residential complexes equipped with the necessary infrastructure, playgrounds, shopping centers and other objects of social significance. The article discusses the trend of re-profiling of the territory on the example of the city of St. Petersburg, which has significant capacity in this area. The old city center is saturated with industrial areas that are currently not used for their intended purpose. The needs for residential real estate data are realized by developers who actively repurpose these territories for modern large-scale residential complexes. However, this process is quite time-consuming and requires a lot of design work. At the same time, the re-profiling of the territory should be accompanied by the economic efficiency of these works, an example of the calculation of which is presented in the article.
\end{abstract}

Keywords: urban infrastructure, construction, industrial area, redevelopment, property, design, efficiency.

\section{Introduction}

In fact, re-profiling of modern urban areas is currently a feature of all major Russian cities. This phenomenon is called redevelopment in the form of replacement of buildings in specific areas with projects of another designated purpose. The reasons in most cases are inefficient functioning and neglect of industrial zones, the use of territories other than for their intended purpose, etc. The study of this subject is relevant due to the multiplicity of these projects and the interest they arouse from the perspective of various sciences. Specifically, redevelopment of urban territories refers to an area of economic and

\footnotetext{
*Corresponding author: $\underline{\text { 99161122142@mail.ru }}$
} 
construction knowledge that, viewed in the aggregate, allows an assessment of the engineering and financial feasibility of these projects.

The purpose of this article is to explore the essence and the purpose of re-profiling of urban areas using as an example the development of St. Petersburg.

Research objectives are to:

- Explore the essence and options for redevelopment of urban areas;

- Study the particular features of the construction process and organization of production in the redevelopment of urban areas as exemplified by construction projects in St. Petersburg;

- Assess the scale of redevelopment of urban areas in St. Petersburg;

- Identify shortcomings and provide recommendations to improve the organization of production in the redevelopment of urban areas in St. Petersburg.

Research methods.

The methods used in this study include: the method of working with source materials, the method of comparative analysis in the course of research, general scientific logistic approaches of deductive and inductive analysis of the material.

\section{Main part}

The term of the re-profiling of urban areas has not established itself in the scientific community. The most commonly word used in this context is its equivalent redevelopment. This is the most important process in the development of urban areas that contributes to improving the quality and comfort of the urban environment. Notably, reprofiling, or redevelopment, offers new construction projects to developers, gives new jobs to urban residents, and contributes to the expansion of the social infrastructure thus generating increased budget revenues from newly opened retail and service facilities.

In terms of scientific research, the most precise definition of redevelopment has been proposed by M. V. Volovik [1], who describes it as integrated new development of territories or individual construction projects involving a change in the functional purpose of the site. The same interpretation can also be given to re-profiling of territories, which also includes a full cycle of construction operations and a change of the purpose of use of the land plot and the buildings and structures located thereon.

At the same time, A. A. Lapidus [2] defines this term as redevelopment of the territory and all properties thereon starting from a change in the intended purpose of the land plot. In fact, both terms have the same focus thus enabling a conclusion on proximity of the studied definitions of «re-profiling» and «redevelopment» of urban areas.

This makes it possible to move on to a further study of the types of re-profiling and their economic justification, operating with both concepts. It should be clarified that various development options are applied in the practice of urban area re-profiling. The most significant scenarios are illustrated [2] in Fig. 1. 
Re-profiling or reconstruction of old industrial buildings for further use as administrative or storage facilities

Preservation of the full or partial industrial function of the facility in conjunction with the introduction of new production technologies
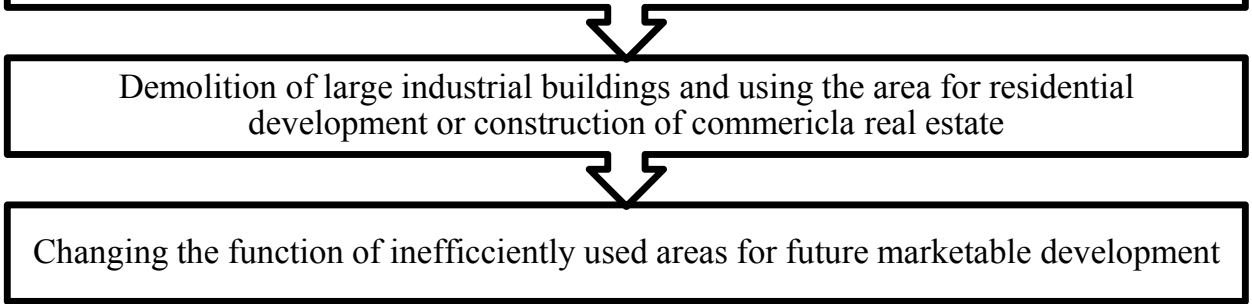

Fig. 1. Forms of urban area re-profiling.

In most cases, redevelopment projects are based in non-operational industrial areas or in areas with dilapidated and old residential buildings and involve the construction of new comfortable residential complexes or social infrastructure facilities instead. As a result, this process contributes to solving the housing problem in urban areas by increasing the number of apartments built and boosting competition in the market.

However, redevelopment is a rather costly and complicated type of construction. Most such projects involve clearing the area of existing buildings, preparatory work for new construction, and the construction of new facilities. As a result, area redevelopment project becomes cost-intensive [3].

Economic benefits and feasibility of demolition and construction of the new territory depends on the specific project: the state of engineering structures, the architecture (in terms of some parameters, not all industrial buildings can be re-profiled into offices or converted into housing), the availability of utilities connected to the territory, the surrounding area and much more. Redevelopment projects for industrial facilities are often unrealized due to a high price of land. It should also be taken into account that obtaining land for construction of facilities in the city center is becoming increasingly difficult because of the compaction of the central parts of most major cities and the emergence of new requirements for developers. In any case, area redevelopment requires investment, which is most often raised externally.

Area redevelopment projects are implemented on a particularly extensive basis in Moscow and St. Petersburg. Thus, in St. Petersburg alone, the potential of industrial areas, which can be allocated for housing, totals at least 1.6 trillion rubles [4].

The popularity of former industrial zones is due to the fact that they have no equivalent alternative. Spot development of the nineties and noughties actually exhausted the land within the developed urban areas of St. Petersburg. Active growth of housing has led to the development of peripheral areas and lands of the Leningrad region adjacent to the city. However, quite soon the demand for these locations seriously decreased because of the numerous single-type projects, reluctance of residents to live «at the construction site», congestion of roads, and problems with social infrastructure. Consequently, developers started looking for new locations, more attractive for potential customers, in the inner city districts, where there is practically no free land. Developers are paying more and more attention to assessing the prospects for redevelopment of certain areas making part of the so-called «gray belt» of St. Petersburg [5]. 
There are few plots for new construction directly in the historic center, while the territories of the «gray belt» are notable for their proximity to the center, transport accessibility and views. They will always be in demand. Statistics confirm the rapid advancement of this process. In total, there are 26 industrial zones scheduled for urban transformation according to the General Plan. Their total area is about 6,100 hectares. Some 4,200 of them can be redeveloped [6].

The plans for the remaining areas provide for partial preservation of the existing production, transportation, utility and social facilities and partial development of the territory for the street and road network and other needs. Thus, at the end of 2019, redevelopment projects in St. Petersburg covered some 170 hectares of urban land, a figure comparable with the results of 2018 (187 hectares). In total, since the noughties, about 1,600 hectares of former industrial areas have been involved in the redevelopment process [5], as illustrated by Fig. 2.

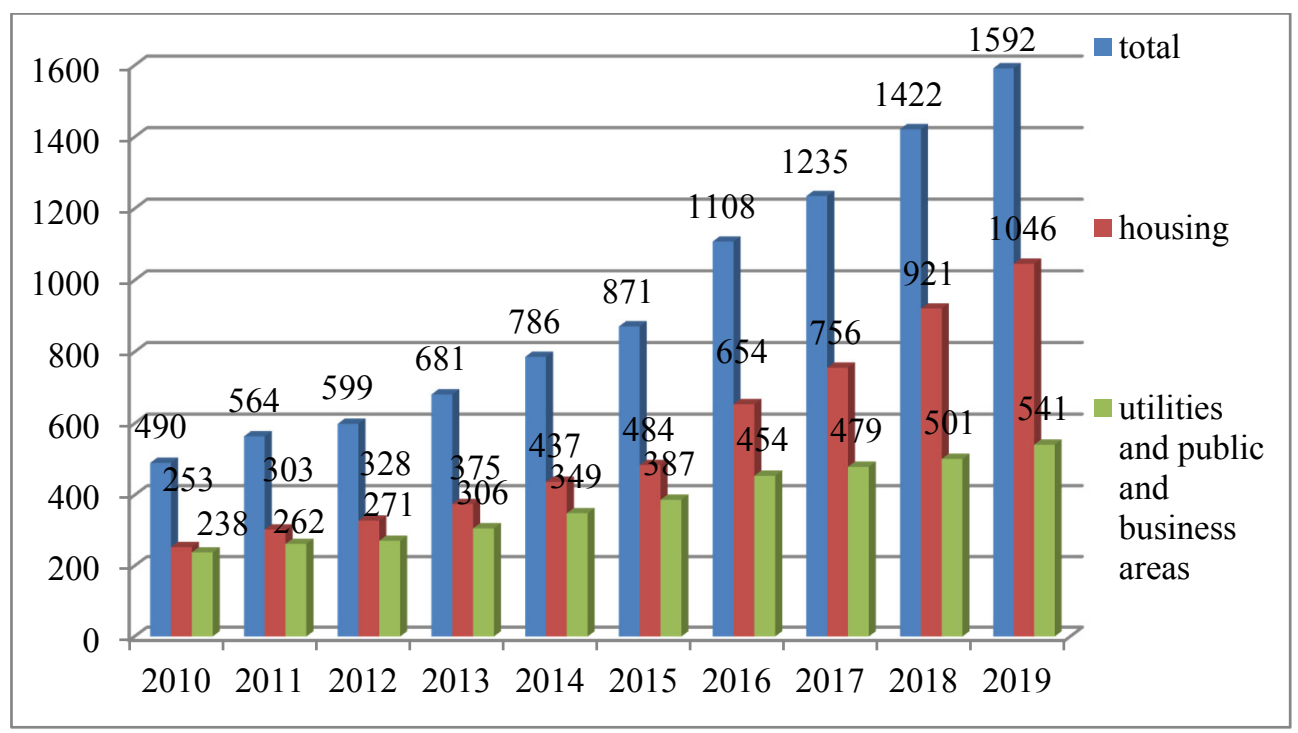

Fig. 2. Dynamics of redevelopment projects in St. Petersburg in 2010-2019, cumulatively, hectares.

There is an obvious general trend of increasing the share of housing in industrial area redevelopment projects within the city limits. The period between 2010 and 2019 witnessed a more than five times gain in that share, a fact that proves the importance of these projects and the possibility of stepping up the pace of redevelopment in St. Petersburg.

The most highly-demanded projects [6], completed or under construction in former industrial zones, are shown in Table 1. 
Table 1. The most highly-demanded projects, completed or under construction in former industrial zones, as of 2020 .

\begin{tabular}{|c|c|c|c|c|}
\hline $\begin{array}{l}\text { Residential } \\
\text { complex }\end{array}$ & Former territory & Class & Site area & Total area of flats \\
\hline Two Epochs & Escalator plant & comfort & $\begin{array}{l}10,098 \\
\text { sq. m }\end{array}$ & $25,937.53$ sq. $\mathrm{m}$ \\
\hline Lake House & Spinning factory & comfort & $\begin{array}{l}5,968.7 \\
\text { sq. } \mathrm{m}\end{array}$ & 7,356.4 sq. $\mathrm{m}$ \\
\hline Atlanta & Avant-Garde plant & comfort & $\begin{array}{l}15,584 \\
\text { sq. m. }\end{array}$ & $24,114.2$ sq. $\mathrm{m}$ \\
\hline Atlanta 2 & Avant-Garde plant & comfort & $\begin{array}{l}15,669 \\
\text { sq. m. }\end{array}$ & $35,900.87$ sq. $\mathrm{m}$ \\
\hline Stockholm & Redan plant & elite & $\begin{array}{l}19,268 \\
\text { sq. m. }\end{array}$ & $24,114.2$ sq. $\mathrm{m}$ \\
\hline $\begin{array}{r}\text { Riverside } \\
\text { (2 stage) } \\
\end{array}$ & $\begin{array}{c}\text { Leningrad Northern } \\
\text { Plant } \\
\end{array}$ & elite & $\begin{array}{l}68,404 \\
\text { sq. m. }\end{array}$ & $51,021.09$ sq. $\mathrm{m}$ \\
\hline Seasons & Petmol plant & comfort & $\begin{array}{l}54,996 \\
\text { sq. m. }\end{array}$ & $26,349.9$ sq. m. \\
\hline Smolniy Prospect & Soft Furniture factory & elite & $\begin{array}{l}26,085 \\
\text { sq. m. }\end{array}$ & $41,603.0$ sq. m. \\
\hline $\begin{array}{l}\text { Europe City } \\
\text { (3 stage) }\end{array}$ & Electric plant & business & $\begin{array}{l}73,576 \\
\text { sq. m }\end{array}$ & $27,021.06$ sq. $\mathrm{m}$. \\
\hline Moscow Quarter & Electrosila plant & business & $\begin{array}{l}21,686 \\
\text { sq. } \mathrm{m}\end{array}$ & $46,084.89$ sq. m \\
\hline Sofia & Ceramics brick factory & comfort & $\begin{array}{l}48,282 \\
\text { sq. } \mathrm{m}\end{array}$ & $\begin{array}{l}235,911.28 \mathrm{sq} . \\
\mathrm{m}\end{array}$ \\
\hline $\begin{array}{c}\text { Leontievskiy } \\
\text { Cape } \\
\end{array}$ & Volcano plant & elite & $\begin{array}{c}27,254 \\
\text { sq. } \mathrm{m}\end{array}$ & 57,226 sq. m \\
\hline Tsar Capital & $\begin{array}{c}\text { Moskovskaya- } \\
\text { Tovarnaya station }\end{array}$ & comfort & $\begin{array}{c}27,139 \\
\text { sq. } \mathrm{m}\end{array}$ & 206,000 sq. m. \\
\hline
\end{tabular}

As far as the projects listed in the table are concerned, it should be noted that one of the areas that are most actively being redeveloped and popular with developers in St. Petersburg is Parnas industrial zone.

This area is a leader in terms of the number of square meters of housing that have already been built here or will be completed in the foreseeable future. Redevelopment is a complex issue to be harmoniously coordinated with the development of social and transport infrastructure, as reflected in the new and subsequent general plans for the development of the territory of St. Petersburg.

Successful redevelopment of industrial areas can be exemplified by the reconstruction project of the Red Textile Worker plant on Sinopskaya embankment, which was reprofiled into a Unified Document Center [7]. The project included complete reconstruction of the plant with addition of one floor.

Fidel Business Center is a five-story building of the former Pahl Weaving Manufactory, built in the 19th century. Following the revolution, the factory was named after Nogin, and for many years it was quite a successful enterprise. After the perestroika, the factory was renamed into the Alexander Nevskiy Manufactory. The industrial territory of the Kirov 
Spinning and Threading Mill was created in 1937 as a result of combining the spinning and threading factories, which were built here in the 19th century.

Fig. 3 shows a photograph of the building before the reconstruction.

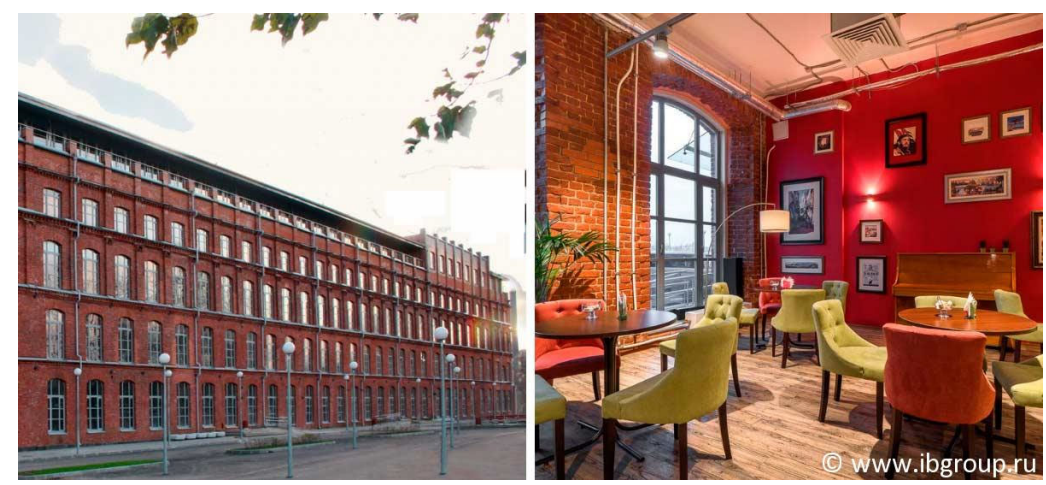

Fig. 3. A photograph of the building before the reconstruction.

The factory was redeveloped ten years ago into a $\mathrm{B}+$ business center, which is currently positioned as «business loft». The red bricks, high ceilings (between three and five meters) and expanded windows - all this is truly in full consistency with the modern «loft» style. Fig. 4 shows a photograph of the redeveloped building.

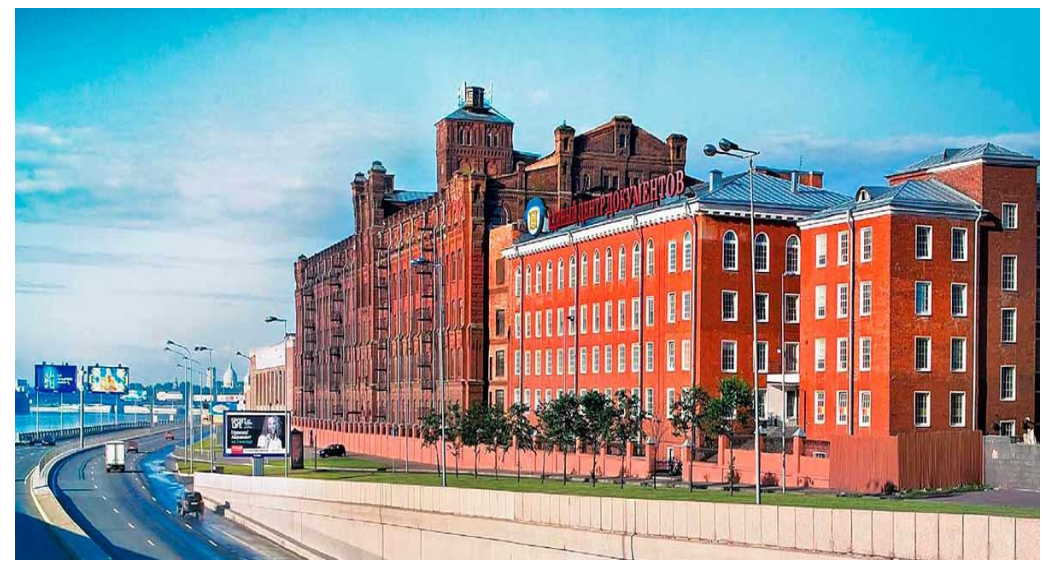

Fig. 4. A photograph of the redeveloped building.

This building is now familiar to every resident of the city. Address: 10-12D, Krasnogo Tekstilschika st.

The Unified Document Center is the first integrated space not only in St. Petersburg, but also in Russia, offering various types of public and legal services simultaneously in a fundamentally new environment. The building was given a new life: there are spacious waiting rooms, comfortable dining rooms and cafes, a mother and baby room, a pharmacy, bank branches, equipped parking for bicycles and baby carriages, and a large parking lot. The modern complex of buildings is designed to meet the needs of disabled visitors.

However, it should be noted that the re-profiling of this building was accompanied by a complex design process involving technical expertise on the possibility of additions to the building, as well as strengthening its foundations, the remodeling of the entrance and the 
external appearance of the building, which had to have a modern look, while not disrupting the overall style of the old city.

Moreover, additions were implemented concurrently with comprehensive refurbishment of the frame and interior partitions of the building that included changes in the floors and complete redesigning of the existing part of the building.

The upper floor was added to the building using frame-hung glazed elevator shafts. The shaft is fixed to the façade on the side, where the staircase adjoins, and ends at the height of the entrance door.

The reconstruction included reinforcement of the old structures bearing the load of the added floor.

As a result, the project was carried out within the permissible values of the urban planning restrictions. Another evacuation staircase leading to the street was equipped in the building to provide evacuation. All solutions were coordinated with the chief architect of St. Petersburg. The project made it possible to use the building for a new purpose. At the same time, its reconstruction pays off, because its redevelopment has turned out a product that brings the investing owner a stable income in the form of rent from tenants of the building.

Table 2 shows an aggregated calculation of the costs of reconstruction [8].

Table 2. An aggregated calculation of the costs of reconstruction of the Red Textile Worker plant, rubles.

\begin{tabular}{|c|c|}
\hline Costs & Rubles \\
\hline Designing & $25,000,000$ \\
\hline Investment in construction works, including & $183,800,000$ \\
\hline Construction of an additional floor of the building & $39,000,000$ \\
\hline Interior decoration & $25,000,000$ \\
\hline Reconstruction of the façade & $50,000,000$ \\
\hline Reconstruction of the roof & $40,000,000$ \\
\hline Strengthening of the foundation & $15,800,000$ \\
\hline Construction of a parking lot and landscaping & $14,000,000$ \\
\hline Total costs & $208,800,000$ \\
\hline
\end{tabular}

The costs of the building's reconstruction totaled 208,800,000 rubles. However, it should be noted that the building had been idle and had not brought any benefit to the owner. Moreover, its maintenance (electric power, heating, security of the territory, etc.) required up to $30,000,000$ rubles annually. Therefore, it was more profitable for the owner from this point of view to re-profile the building. Its payback period is $208,800,000 / 30,000,000=$ 6.9 years (about 7 years).

However, the building is currently bringing a significant profit from leasing space to a Multifunctional Public Services Center and other businesses that render notary, legal and other services. A calculation of economic efficiency [8] is given in Table 3.

Table 3. A calculation of economic efficiency of the reconstruction of the Red Textile Worker plant, rubles.

\begin{tabular}{|c|c|}
\hline Costs & Amount \\
\hline Total area of the building, sq. m. & 11,336 \\
\hline Usable area, sq. m. & 9,500 \\
\hline Rent, ruble per sq. m & 4,500 \\
\hline Average maintenance costs, per sq. m & 1,100 \\
\hline Owner's income, rubles per year & $513,000,000$ \\
\hline Owner's expenses, rubles per year & $124,696,000$ \\
\hline Owner's profit, rubles per year & $388,304,000$ \\
\hline
\end{tabular}


Thus, the payback period on the owner's capital investment in terms of profitability of the building will be less than one year. Needless to say that this calculation is based on the full occupancy of the building by tenants without taking into account the advertising costs of the leased space. However, in any case, the owner's benefit from re-profiling this area is obvious.

This project also has a social meaning as follows:

1) Enhancing the quality of public services by providing them in a single location;

2) Liquidation of dilapidated and unused industrial assets with significant physical and moral deterioration;

3) Improvement of the area adjacent to the city center.

\section{Conclusions}

The presented study has proved the importance of urban redevelopment projects and the potential of their enhancement.

However, it should be noted that in 2020 , as well as in early 2021 , the process of redevelopment of industrial areas slowed due to the current economic situation, forcing developers to take a wait-and-see approach. The unfavorable economic situation is far from being the only reason for the slow pace of redevelopment of industrial areas in St. Petersburg. The lack of a full-fledged regulatory framework often forces developers to refuse to aim at the redevelopment of industrial areas and encourages them to choose more remote, but free areas.

Many owners of industrial areas, seeing the interest of developers, start the process of transferring their land for residential development, as it immediately increases the value of the asset.

At the same time, the regulatory framework for area re-profiling has not been fully developed and, at the level of each region, there are discrepancies with federal legislation. For this reason, it is important to form unified standards and requirements for the organization of production operations at such sites and for re-profiling projects that must comply with the trends in the preservation of urban cultural heritage sites and take into account the needs of the residents [9-14].

\section{References}

1. M. V. Volovik, Modern approaches to solving the issues of organizational and technological design (M. V. Volovik, M. N. Ershov, A. V. Ishin, A. A. Lapidus, O. P. Lyang, V. I. Telichenko, P. P. Oleynik, D. K. Tumanov, O. A. Feldman, 11 technology and organization of construction operations, Direct text, 3, 10-16, 2013)

2. A. A. Lapidus, Redevelopment of industrial areas, The Herald of Nosov Magnitogorsk State Technical University, 4 (2019) URL: cyberleninka.ru/article/n/redevelopmentpromyshlennyh-territoriy (last accessed: 05.03.2021)

3. V. V. Molodin, E. N. Likhachev, Evolution of architectural and construction solutions for industrial buildings of Novosibirsk, Polzunovskiy Herald, 4-1, 123-127 (2013)

4. E. G. Oykhman, Business re-engineering: re-engineering of organizations and information technologies (Finances and Statistics, Moscow, Russia, 333, 1997)

5. P. P. Oleinik, Organization of construction operation (Monograph, ASV Publishers, Moscow, Russia, 576, 2010)

6. S. A. Sinenko, Information design technology for organization of construction operations (Systems Engineering and Computer Science, Moscow, Russia, 258, 1992) 
7. D. V. Topchiy, Preparation of former industrial sites for civil construction, Technology and organization of construction operations, 4, 34-41 (2014)

8. D. V. Topchiy, S. G. Muzychenko, S. D. Gotsoev, Organizational and engineering modelling of re-profiling of industrial facilities, Innovation and Investment, 8, 147-150 (2019)

9. D. Kremcheeva, E. Kremcheev Use of a Quality Management System at the Iron and Steel Enterprise, Journal of Mechanical Engineering Research and Development, 41, 1, 151-155 (2018)

10. D. Latham, Creative Re-use of Buildings (Donhead, Dorset, 2000)

11. A. Leiponen, Managing Knowledge for Innovation: The Case of Business-to-Business Services, Journal of Product Innovation Management, 23(3), 238-258 (2006)

12. A. Lievens, R. K. Moenaert, New Service Teams as Information-Processing Systems Reducing Innovative Uncertainty, / Journal of Service Research, 3(1), 46-65 (2000)

13. Y. S. Lincoln, E. G. Guba, Naturalistic Inquiry (Sage Publications, Newbury Park, California, 1985)

14. L. P. Lingaitis, S. Mjamlin, D. Baranovsky, V. Jastremskas, Prediction Methodology of Durability of Locomotives Diesel Engines, Eksploatacja i Niezawodnosc - Maintenance and Reliability, 14(2), 154-159 (2012) 